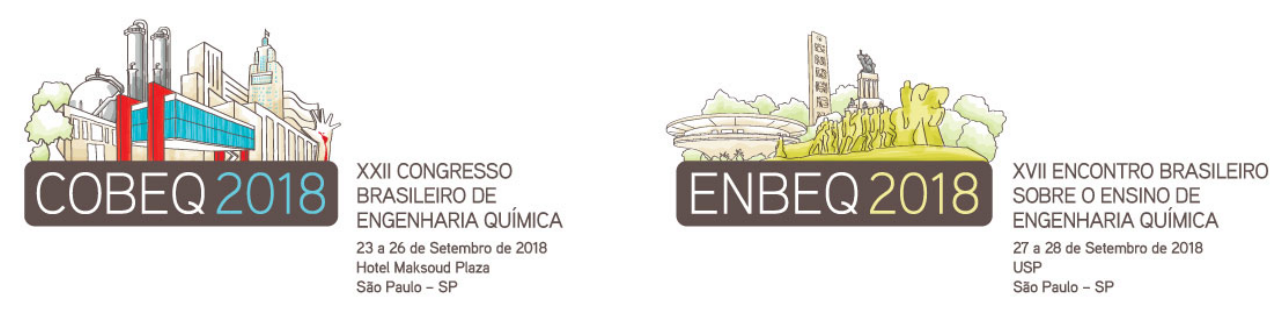

\title{
DEVELOPMENT OF CERAMICS ENAMEL USING BOTTLE GLASS
}

\author{
COSTA WA ${ }^{1,2}$, OLIVEIRA MS ${ }^{1}$, SILVA APS ${ }^{1}$, SILVA FILHO FGS ${ }^{3}$, BEZERRA FWF ${ }^{1}$, \\ MARTELLI MC ${ }^{2}$ \\ ${ }^{1}$ Federal University of Pará, Technology Institute, LABEX/FEA \\ ${ }^{2}$ Federal University of Pará, Technology Institute, Faculty of Chemical Engineering \\ ${ }^{3}$ Federal University of Pará, Technology Institute, Faculty of Electrical Engineering \\ E-mail: Wanessa.almeida712@yahoo.com.br
}

\begin{abstract}
The Icoaraci district is an important ceramic pole of Pará state (Brazil). The improvement of certain stages ranging from the treatment of the raw material to the ceramic finish is an important point to the production and marketing of the pieces. One of these improvements is the production of a coverage that can be applied to the ceramic surface, characterized by a thin continuous layer of a material called enamel or glaze, which contributes to its aesthetic, mechanical, electrical and sanitary aspects. This study aimed to develop a suitable glaze for use on Icoaraci ceramics, in which bottle glass was used as the main component, varying the amounts of compounds and their firing temperatures. The characterization of the raw materials was performed by X-ray fluorescence, Thermogravimetric and Differential Thermal Analysis. The best result was firing at $900^{\circ} \mathrm{C}$, with $5 \%$ borax, during 3 hours.
\end{abstract}

\section{INTRODUCTION}

Among the stages of ceramic production, firing is one of the most important because it may influence the quality of the ceramics obtained. Due to the temperature reached during the process, the products acquire their final properties, such as brightness, color, porosity, flexural strength, resistance to chemical attacks and others (Pinheiro and Holanda, 2010).

The use of enameling techniques has significant effect on the pieces value and provides greater internal protection, since most pieces will be used as tableware, which would justify the enamel use.

Many ceramic products such as sanitary ware, tableware, electrical insulators, and other coating materials, receive a thin continuous layer of a material called enamel or glaze, which, after firing, becomes glassy. The enamel can be defined as a vitreous, water insoluble compound, which is obtained by melting of certain mixtures of raw materials (Casagrande et al., 2008). This glass layer contributes to the improvement of aesthetic, sanitary, mechanical and electrical properties. The glaze compositions and formulations depend on the firing temperature, the ceramic piece and enamel characteristics (Lira and Alarcon, 2004).

In this sense, the objective of this work was to develop a type of ceramic glaze using bottle glass.

\section{MATERIALS AND METHODS}



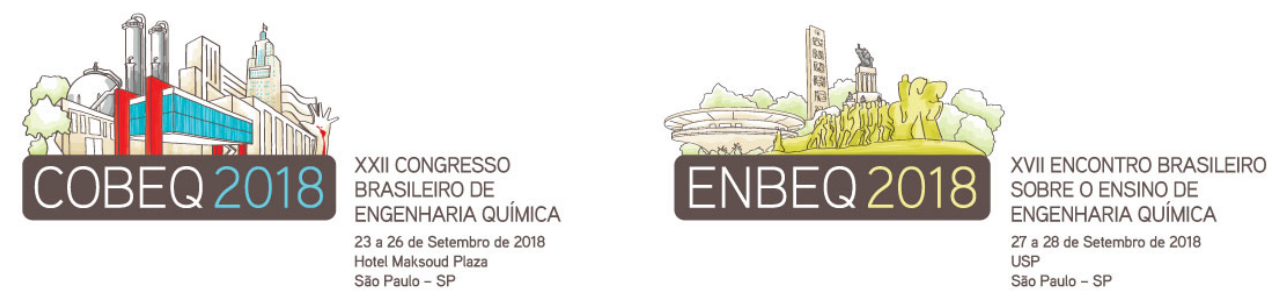

The raw materials used were: kaolinitic clay, bottle glass, carboxy methyl cellulose (CMC), water-white glue solution, kaolin and borax (Reis, 2010).

The equipment used was: Ball mill, precision balance, press, muffle, drying oven, glassware and porcelain grail.

The methodology followed was: The raw material was characterized by the chemical analyses: X-ray fluorescence, thermogravimetric analysis (TGA) and differential thermal analysis (DTA).

\subsection{Preparation of the Enamel and Its Composition}

For the preparation of ceramic glaze, firstly it was necessary to grind the bottle glass. A mill of alumina balls was used in the experiments. The total milling time was 11 hours. The clay was collected on the river Tucunduba (Belém-Pará-Brazil). Then, it was cleaned, dried in forced air circulation oven for 12 hours at $60^{\circ} \mathrm{C}$ and grinded in a ball mill for 2 hours.

To prepare the CMC solution, 10g of CMC were diluted in 1 liter of water, heated in a water bath until boiling and complete dissolution. After that, the solution cooled naturally and was stored in a jar.

The water-glue solution was prepared at the proportion 1:10 (glue:water). Borax was added in percentages of $0,5,10$ and 15 .

In all experiments, $50 \mathrm{~g}$ of bottle glass, $0.25 \mathrm{~mL}$ of water-glue solution, $1 \mathrm{~g}$ of clay, 1 $\mathrm{mL}$ of CMC and $50 \mathrm{~mL}$ of distilled water were mixed in a porcelain grail. The compositions can be seen in Table 1 . The enamel was poured in each ceramic piece and applied with a brush. The firing temperatures were tested in a range of 850 to $1000^{\circ} \mathrm{C}$ (Reis, 2010).

Table 1 - Content of material according to each experiment

\begin{tabular}{ccccccc}
\hline Exp & $\begin{array}{c}\text { Bottle } \\
\text { Glass } \\
(\mathbf{g})\end{array}$ & $\begin{array}{c}\text { Water } \\
(\mathbf{m L})\end{array}$ & $\begin{array}{c}\text { Water- } \\
\text { glue } \\
\text { solution } \\
(\mathbf{m L})\end{array}$ & $\begin{array}{c}\text { CMC } \\
(\mathbf{m L})\end{array}$ & $\begin{array}{c}\text { Borax } \\
(\%)\end{array}$ & $\begin{array}{c}\text { Temperature } \\
\left({ }^{\circ} \mathbf{C}\right)\end{array}$ \\
\hline 01 & 50 & 50 & 0.25 & 1 & - & 900 \\
02 & 50 & 50 & 0.25 & 1 & 5 & 900 \\
03 & 50 & 50 & 0.25 & 1 & 10 & 900 \\
04 & 50 & 50 & 0.25 & 1 & 10 & 850 \\
05 & 50 & 50 & 0.25 & 1 & 15 & 850 \\
06 & 50 & 50 & 0.25 & 1 & - & 1000 \\
\hline Exp- experiment; T - temperature; ${ }^{\circ} \mathrm{C}-$ Celsius degrees.
\end{tabular}

\section{RESULTS AND DISCUSSION}

The technique of internal pouring was used because there was a little amount of enamel. Then, the brush was used to spread the enamel and prevent the appearing of excess spots (Chavarria, 1998).

\subsection{Chemical Analyses}



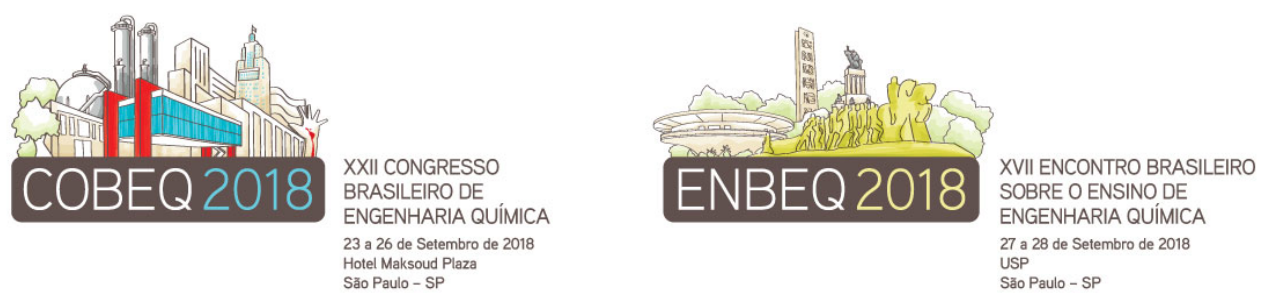

Table 2 shows the results of X-ray fluorescence of the river clay and bottle glass. The presence of $\mathrm{SiO}_{2}$ in the bottle glass can be highlighted, since it's a glassy material. The fluxing oxides $\mathrm{CaO}$ and $\mathrm{Na}_{2} \mathrm{O}$ also appear in considerable quantities.

\begin{tabular}{|c|c|c|}
\hline Substance & $\begin{array}{c}\text { River Clay } \\
(\%)\end{array}$ & $\begin{array}{c}\text { Bottle Glass } \\
(\%)\end{array}$ \\
\hline $\mathrm{Al}_{2} \mathrm{O}_{3}$ & 12.929 & 1.625 \\
\hline $\mathrm{SiO}_{2}$ & 68.331 & 71.992 \\
\hline $\mathrm{CaO}$ & 0.170 & 12.332 \\
\hline $\mathrm{MgO}$ & 0.717 & 0.057 \\
\hline $\mathrm{BaO}$ & 0.151 & 0.050 \\
\hline $\mathrm{Na}_{2} \mathrm{O}$ & 0.382 & 11.574 \\
\hline $\mathrm{K}_{2} \mathrm{O}$ & 1.385 & 0.520 \\
\hline $\mathrm{Fe}_{2} \mathrm{O}_{3}$ & 5.225 & 0.061 \\
\hline $\mathrm{TiO}_{2}$ & 0.954 & - \\
\hline $\mathrm{PbO}$ & - & 0.025 \\
\hline $\mathrm{ZrO}_{2}$ & 0.053 & 0.018 \\
\hline $\mathrm{SrO}$ & - & 0.064 \\
\hline $\mathrm{P}_{2} \mathrm{O}_{5}$ & 0.033 & 0.047 \\
\hline $\mathrm{SO}_{3}$ & - & 0.190 \\
\hline
\end{tabular}

Figure 1 shows the thermogravimetric and differential thermal analyses in the river clay. The green curve is the weight loss with the increasing temperature; the red curve represents the characteristic points of the materials present in the clay. At $95^{\circ} \mathrm{C}$, there is a downward shift, which conventionally represents an endothermic reaction and the elimination of water. At $335^{\circ} \mathrm{C}$, there is an upward deflection, which conventionally represents an exothermic reaction and the carbonization of organic materials. At the temperature of $581^{\circ} \mathrm{C}$, kaolinite can be seen and at $498{ }^{\circ} \mathrm{C}$, it possibly can be seen a mix of kaolinite and montmorillonite (Reis, 2012).

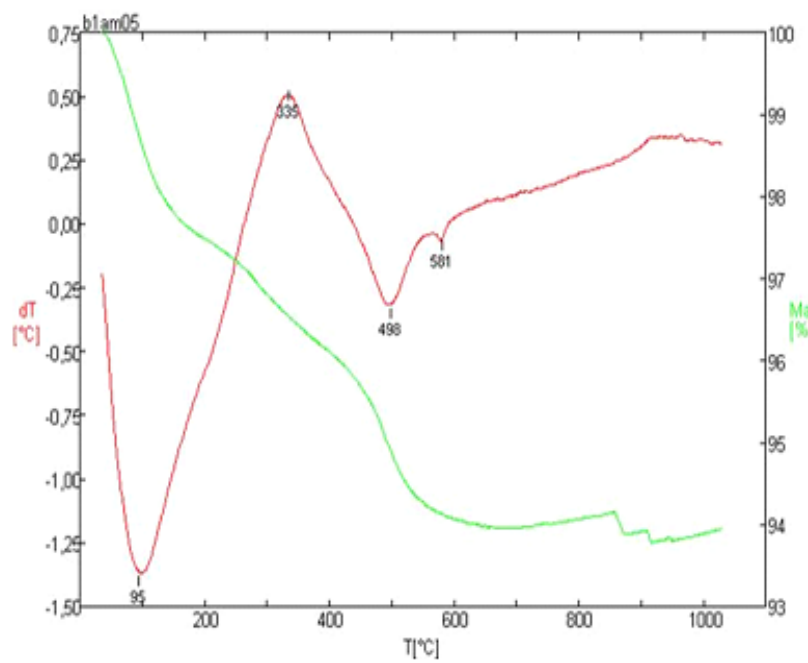

Figure 1 --Thermogravimetric (TG) and differential thermal (DTA) analyses of the river clay 

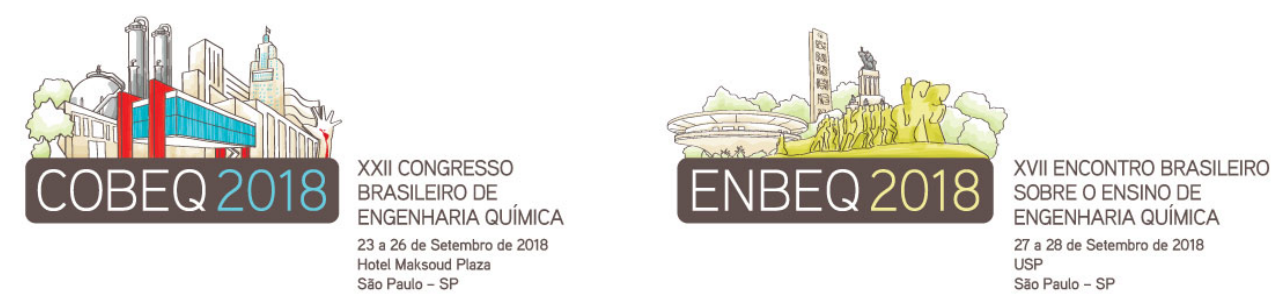

\subsection{Enamel Firing Results}

Six firing experiments were performed. To choose the best one, it was taken into account the appearance of the glass layer, its thickness and the absence of defects such as bubbles and cracks (Mckingley et al., 2009). Among all, the experiment 02 was chosen (Figure 2) as the best one. The glassification happened, however the glaze application presented flaws such as bubbles from the water vapor arising through the enamel itself (due to pre-existing moisture) and cracks due to the ceramic craft already present these flaws before the glaze application.

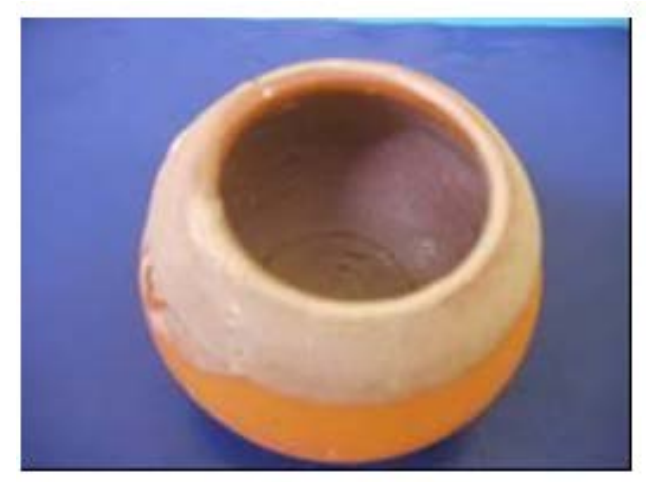

Figure 2 -- Exp 02 - Bottle glass, firing at $900^{\circ} \mathrm{C}$, with $5 \%$ borax

\section{CONCLUSION}

The best result was firing at $900{ }^{\circ} \mathrm{C}$, with $5 \%$ of borax. Glassification ocurred, however it presented flaws such as bubbles from the water vapor arising through the piece. The moisture content at the time of enamel application is the major contributing factor in the final firing result, since it favors the appearance of blisters on the enamel's surface.

\section{REFERENCES}

CHAVARRIA J. Ceramics class. Glazes. 1st Ed Buenos Aires. Editorial La Isla, 1998.

CASAGRANDE MC, SARTOR MN, GOMES V, DELLA VP, HOTZA D, OLIVEIRA AD. Reaproveitamento de resíduos sólidos industriais: processamento e aplicações no setor cerâmico. Cerâmica Industrial, v. 13, n. 1/2, p. 34-42, 2008.

LIRA C, ALARCON OE. Seleção de esmaltes cerâmicos utilizando um delineamento experimental segundo Taguchi (Ceramic glaze obtaining and selection applying Taguchi experimental design). Cerâmica, v. 50, p. 308-317, 2004.

MCKINLEY K, EVELE H, BALDWIN C. Analysis of Fracture in Porcelain Enamels. In: Manuscript for the 22nd International Enamellers Congress. 2012.

PINHEIRO BCA, HOLANDA JNF. Efeito da temperatura de queima em algumas propriedades mecânicas de cerâmica vermelha. Cerâmica, v. 56, n. 339, p. 237-243, 2010.

REIS AWC. Desenvolvimento e aplicação de esmalte na cerâmica de Icoaraci. Trabalho de Conclusão de Curso (Graduação em Engenharia Química) - Instituto de Tecnologia. Universidade Federal do Pará. Belém, 2010.

REIS AW, MARTELLI MC, NEVES RF. Enamel Development and Application on the Pottery of Icoaraci. Materials Science Forum. v. 727, Trans Tech Publications, p. 681-685, 2012. 